Зуб C.B., співробітник НН Інституту євроінтеграиійних досліджень ДВНЗ «Ужсгородський національний університет»

(м. Ужгород, Украйна)

\title{
ІННОВАЦІЙНА ДІЯЛЬНІСТЬ В ОСВІТІ І НАУЦІ КРАЇН ВИШЕГРАДСЬКОЇ ГРУПИ
}

У статті розглядаються пріоритетні напрями інноваційної діяльності в країнах вимеградської групи, питання реалізачії програм інноваційного розвитку та їх результати. Зосереджено увагу на інструментах, які надали можливість державам досягти успіхів у створенні сприятливого інноваиійного середовища.

Ключові слова: інновачійна діяльність, Вишеградська група, пріоритетні напрями діяльності, програми інновачійного розвитку, иільові програми.

The article deals with the priorities of innovative activity in Visegrad Group countries, issues of implementation of innovative development programs and their results. Concentrated on tools that have enabled states to succeed in creating a favorable innovative environment.

Keywords: innovative activity, Visegrad Group, priority directions of activity, innovative development programs, targeted programs.

Відносини з країнами Вишеградської четвірки (В-4) для України завжди мали фундаментальне значення. По-перше, три 3 чотирьох країн Вишеградського об'єднання є сусідніми для України державами, з якими вона мала історично дружні відносини. А, по-друге, всі чотири країни стали прикладом успішного набуття членства в $С С$, а відтак підтримка та авторитет об'єднання для просування євроінтеграційних прагнень України перетворилися на цінне джерело запозичення корисного досвіду.

\section{Словаччина}

Загальна стратегія розвитку науки та інновацій у Словаччині стала дороговказом для політиків і адміністраторів усіх рівнів. Крім університетів та науково-дослідних інститутів Словацької академії наук, основними ініціаторами та виконавцями плану інноваційних дій $є$ новостворені центри перспективних технологій, центри передових досліджень і центри трансферу технологій, науково-технологічні парки та наукові центри. Вони тісно співпрацюють 3 великими й малими підприємствами, а також сприяють створенню нових інноваційних підприємств, які на початковому етапі підтримує держава [1]. Спільна та узгоджена робота всіх ланок ланцюга 
інновацій, організована за планом дій та загальною стратегією інноваційного розвитку, почала давати результати.

\section{Розроблення стратегії інноваційного розвитку}

Одним $з$ основних пунктів стратегії інноваційного розвитку є капітал для інновацій. Під цим розуміється ініціювання інноваційної діяльності, підтримка фондів капіталу 3 підвищеним ризиком, а також створення системи, яка б полегшувала приватні інвестиції в MSP.

Наступними є інвестиції в інноваційні підприємства. Тут мається на увазі інвестування в дослідження та розвиток на окремих фірмах, надання технологічних кредитів, нові інвестиції з високим інноваційним потенціалом, заохочення інвестицій, що мають важливе значення для економіки, інвестиції в туристичні продукти та послуги, які мають не тільки регіональне значення.

Ще одним важливим пріоритетом стратегії $є$ поширення (дифузія) інновацій. Сюди належить підтримка кооперативних зв'язків, що мають не тільки регіональне значення, підтримка ряду проінноваційних інституцій у сфері бізнесу, які мають не тільки регіональне значення, підтримка осередків інноваційності, а також управління інтелектуальною власністю.

Політична підтримка співпраці університетів з бізнесом в Словаччині в основному відображена в декларативних стратегічних документах. Одним 3 таких документів є Довгостроковий план освітньої, науково-дослідної, творчої та іншої діяльності в університетах до 2014 року. Першим пріоритетом співпраці університетів з бізнесом в цьому документі названо поліпшення якості науки та освіти у словацьких вузах і зазначено, що сучасні підприємства будуть співпрацювати лише 3 тими академічними інституціями, які іiі забезпечуватимуть. Підтримка 3 боку уряду цього напряму спирається винятково на рекомендації і реалізується в основному через проекти, що фінансуються Свропейським Союзом.

Так, для прикладу, Технічний університет м. Кошице [2] має тісні зв'язки 3 місцевими і міжнародними промисловими партнерами. Співпраця 3 бізнесом реалізується в першу чергу через діяльність численних сучасних лабораторій, більшість яких була створена в рамках проектів 3 фінансуванням ЄС. Наприклад, кожна кафедра факультету електронної інженерії та інформатики має власну навчально-наукову лабораторію, яка забезпечує не тільки практичну складову навчальної програми, але й стає першим робочим місцем для багатьох студентів. Чимало лабораторій створено завдяки співпраці 3 найбільшими глобальними світовими виробниками IT техніки, мережного устаткування та надавачами IT сервісів: CISCO Telepresence, CISCO IPv6 Lab, Laboratoty IBM, T-System. B комерційних проектах лабораторій поруч працюють професори, студенти i представники організацій замовників. Більшість аспірантів працюють над дисертаціями разом зі своїми потенційними роботодавцями. Студенти заохочуються до складання зовнішніх іспитів 3 метою професійної 
сертифікації (наприклад, професійна сертифікація у сфері інформаційних технологій для роботи з продукцією Cisco Systems).

Розвивається дистанційне навчання (e-learning). Реалізуючи принцип «навчання впродовж життя», Університет надає знання зі спеціалізованих комп’ютерних програм, що необхідні для роботи працівникам підприємств.

Університет намагається розвивати нові напрями діяльності, пов’язані 3 бізнесом. Створено університетський центр інновацій, трансферу технологій i захисту прав інтелектуальної власності UCITT. Адміністрація університету всіляко намагається мотивувати викладачів та науковців до пошуку комерційних проектів. Університет залишає для власних потреб 15\% прибутку за використання бренду, ризики та гарантії, решта розподіляється між виконавцями. Таким чином, у структурі зарплати науково-педагогічних працівників складова отримана за рахунок різних проектів, становить до 40\%.

\section{Угорщина}

\section{Науково-обгрунтована інноваційна політика Угорщини базусться на} таких джерелах:

> Співпраця між користувачами та / або виробниками. Нові гравці приєднуються до інноваційного процесу - ті, хто створює форми співпраці на основі створених знань, які породжують нові можливості.

Модульні конструкції, окремі частини яких можуть бути ініційованими самостійно, але в поєднанні вони утворюють єдину інноваційну систему. Комплекс технологічних інновацій у децентралізованій системі реалізований через нову підтримку в координації та сертифікації.

Інформаційні та комунікаційні технології, якщо їм вдається ефективно використовуватися як єдиний інструмент для інновацій, то значною мірою сприяють трансформації діяльності.

Джерела генерації знань та інновацій, що грунтуються на описаних вище способах, наведені нижче (таблиця 1):

Таблиия 1

Джерела генерації знань та інновацій

\begin{tabular}{|c|c|c|c|c|}
\hline & 1 & 2 & 3 & 4 \\
\hline $\begin{array}{c}\text { Джерела } \\
\text { інновацій }\end{array}$ & Наукові дослідження & $\begin{array}{c}\text { Потреби користувачів і їх } \\
\text { запити }\end{array}$ & $\begin{array}{l}\text { Модульні } \\
\text { системи }\end{array}$ & $\begin{array}{c}\text { Інформаційні та } \\
\text { комунікаційні } \\
\text { технології як } \\
\text { інноваційний засіб }\end{array}$ \\
\hline $\begin{array}{c}\text { Важливі } \\
\text { учасники і } \\
\text { контакти }\end{array}$ & $\begin{array}{c}\text { Створені підприємства } \\
\text { університетам }\end{array}$ & Горизонтальні спільноти & $\begin{array}{l}\text { Винахідники і } \\
\text { модульні } \\
\text { конструктори }\end{array}$ & $\begin{array}{c}\text { IКТ - } \\
\text { постачальники, } \\
\text { керівники, } \\
\text { співробітники, } \\
\text { зацікавлені сторони, } \\
\text { клієнти } \\
\end{array}$ \\
\hline $\begin{array}{l}\text { Трансфер } \\
\text { знань у } \\
\text { промисло } \\
\text { вість }\end{array}$ & $\begin{array}{c}\text { Процеси і продукти, які } \\
\text { мають безпосереднє } \\
\text { значення для } \\
\text { подальшого розвитку } \\
\text { наукових знань }\end{array}$ & $\begin{array}{c}\text { Практичні знання про те, } \\
\text { що спільнота може } \\
\text { досягти значно більше }\end{array}$ & $\begin{array}{c}\text { Інтегративне } \\
\text { знання. Видима } \\
\text { інформація }\end{array}$ & $\begin{array}{c}\text { IКТ-обробляються } \\
\text { за допомогою } \\
\text { систем, } \\
\text { кодифіковане } \\
\text { знання }\end{array}$ \\
\hline
\end{tabular}




\section{Знання та інновації в соціальному вимірі Інновації, засновані на науці}

Організаційна модель вільного переміщення - це істотна риса знань, яка довела свою ефективність. Відповідно до цієї моделі в державному секторі наукових досліджень промисловий сектор може вільно використовуватися. Це знання утворює дуже важливий перехід до приватного наукового дослідження та інноваційної діяльності.

Результати суспільних знань збільшуються завдяки науковому дослідженню та індивідуальним інвестиційним деклараціям; як правило, це загальна база знань, яка для подальших досліджень надає більше переваг для компаній, що інвестують, ніж невигідне конкурентне становище рівного доступу до знань.

\section{Сильні сторони угорської інноваційної системи:}

- високий ступінь відкритості економіки;

- науково-дослідні досягнення високого класу, значні досягнення у галузі фізики, математики, біології, хімії, медицині та інженерній науці;

- $\quad$ наука, технології та інноваційна політика підкріплена відповідною законодавчою базою;

- інститути та рамкові умови стрімко розвивалися i тепер допомагають в багатьох інноваційних відносинах.

\section{Найбільш важливі завдання комплексної інноваційної політики:}

$>$ Угорщина має зміцнити фрагментовану інфраструктуру генерації знань - науково-дослідні інститути, університети, і узгодити їх діяльність, щоб забезпечити відновлення і поліпшення їх здатності до реалізації значних цілей; внесок у досягнення стратегічних цілей національної економіки піддається вимірюванню;

$>$ при прийнятті рішення і його підготовці слід застосовувати суспільну та особисту відповідальність;

для того, щоб розробити і впровадити довгострокову інноваційну стратегію стабільності - вертикальний напрям і горизонтальну координацію - повинні бути встановлені інституційні системи.

Отже, на нашу думку, можна виділити загальні позитивні риси вищенаведених РІC, досвід яких можуть застосувати на практиці і регіони України; це зокрема такі:

- важлива роль науково-дослідних установ і університетів в інноваційній діяльності;

- створення, за участю місцевих органів влади, організацій, які об'єднують в собі як підприємства, які займаються інноваційною діяльність, так і наукові установи, які можуть виконувати роль генератора інновацій; 
значна увага приділяється державній підтримці інноваційної діяльності підприємств малого та середнього бізнесу, зокрема через механізм податкових пільг;

можливість створення нових структур - промислових парків, інноваційних центрів, інкубаторів тощо;

- запровадження програм 3 розвитку інновацій в тих галузях промисловості, в яких регіон має високий конкурентний потенціал;

- тісна мережа зв’язків між суб'єктами інноваційної діяльності.

\section{Польща}

Ринкова комерціалізація нового знання у формі нових продуктів чи технологій є досить складним процесом, 3 великим ризиком. Цей процес вимагає високих і різноманітних повноважень, що, як правило, перевищують можливості наукового середовища та бізнесменів. Водночас діяльність об’єднання «наука-економіка» стримується низкою бар'єрів, що ускладнюють спільну роботу над комерційними проектами. У цих умовах сформувалися спеціалізовані суб'єкти, які діють 3 метою трансферу технології з науки до економіки. Такі суб'скти можуть називатися: центр трансферу технологій, технологічний центр, технологічне агентство, інкубатори інновацій, технологічний парк тощо [3]. Для цієї категорії установ 3 відмінними в багатьох аспектах цілями, організаційно-правовою формою, структурою тощо прийнято вживати загальне визначення - центри інновацій, інституції-посередники, інфраструктура трансферу технологій.

Тому на практиці центри інновацій та підприємництва вважаємо суб'єктами, що реалізують програми підтримки у сфері інноваційності та підприємництва в широкому розумінні цих слів.

\section{Така діяльність відбувається у формах:}

$>$ поширення знань $\mathbf{i}$ вмінь шляхом надання консультацій $i$ проведення навчань, збирання й поширення інформації, надання допомоги у трансфері технологій у рамках діяльності центрів трансферу технологій;

$>\quad$ надання підтримки під час створення нових підприємств у рамках наукових організацій i ВН3, що засновуються студентами, випускниками, аспірантами й науковими працівниками в так званих пре-інкубаторах та академічних інкубаторах підприємництва;

надання комплексних послуг у певному місці за визначеним стандартом, в оточенні наукових інституцій, 3 метою підтримки започаткування інноваційної господарчої діяльності (інноваційні інкубатори, інкубатори підприємництва, технологічні центри);

$>$ створення місць концентрації підприємств (кластерів) та інноваційного середовища шляхом об’єднання в рамках визначеної території послуг для бізнесу та різноманітних форм допомоги для технологічних фірм у рамках технологічних, наукових і промислово-технологічних парків; 
$>$ надання початкової фінансової підтримки (seed $i$ start-up) у формі пара-банкових позичкових i гарантійних фондів; важливим ринковим доповненням цієї категорії $є$ комерційно орієнтовані фонди венчурного капіталу (venture capital).

Центри інновацій є суттєвим елементом кожної сучасної інноваційної системи країни, яка розбудовує основи економіки, базовані на знаннях. Вони відповідають за побудову платформи діалогу та співпраці світу науки й бізнесу, створюючи умови для ефективного трансферу інформації, знань i технологій. Їх активність включає:

$\checkmark \quad$ ініціювання та організацію співпраці всіх партнерів, необхідних для ефективної реалізації інноваційного процесу;

$\checkmark$ визначення інноваційних потреб фірм і комерційних можливостей у рамках наукових організацій;

$\checkmark$ удосконалення механізмів трансферу технологій;

$\checkmark$ створення необхідних для економічного розвитку партнерства різних приватних і публічних суб'єктів;

$\checkmark$ реалізацію програм підтримки в регіонах.

На основі предмета діяльності, місій, цілей і неприбуткового характеру (нон-профіт), у польських умовах до організацій підтримки можна віднести такі види суб'єктів:

організаційно та фінансово самостійні суб'єкти науково-дослідних організацій, активні в сфері комерціалізації нових технологій, такі, що надають підтримку розвиткові місцевої (регіональної) економіки;

Спроможність системи підтримки є функцією визначення потреб для розвитку та будування на іiі основі програм, що створюють можливість оптимального використання обмежених ресурсів. Це зокрема:

програми розвитку підприємництва та трансферу технологій;

суспільно-приватні товариства, засновані 3 ініціативи та при великій організаційній та фінансовій участі державної й місцевої влади, що виконують діяльність, спрямовану на підтримку розвитку, не зобов'язані до генерування прибутків 3 метою розподілу останніх між пайовиками (агентствами місцевого й регіонального розвитку);

- організаційно та фінансово самостійні суб'єкти місцевої адміністрації, націлені на підтримку інноваційності та розвиток місцевої економіки.

Роль центрів інновацій у сучасних економіках динамічно зростає. Це пов'язано 3 відходом від лінійної моделі інноваційного процесу, де домінували акти купівлі-продажу технологічних рішень. Сьогодні трансфер технологій є інтерактивним процесом, у якому присутні різноманітні петлі зворотних зв'язків між передавачами та приймачами інформації. Це виняткова форма процесу спілкування, яка включає різноманітні форми поширення інновацій та технічної освіти. Сьогодні традиційні форми 
трансферу доповнюються такими аспектами: створення малих технологічних фірм та підтримка інноваційних заходів у МСП; технологічний консалтинг i посередництво, інформування про нові технології; ініціювання мереж підтримки, співпраці та кооперації.

Зазвичай ініціатори змін, особи, які пробують упровадити будь-які нові рішення до суспільного й господарського життя, зіштовхуються 3 різноманітними перешкодами - ментальними, фінансовими, політичними, організаційними.

Одним 3 очевидних ефектів було створення Польської асоціації організаторів бізнес-інкубаторів та інноваційних центрів, яка розпочала інформаційну, пропагандистську, консалтингову, навчальну діяльність та лобіювання.

Сьогодні, після 15-ти років набуття досвіду, відбувається повільна консолідація польської моделі інституційної підтримки інноваційної діяльності. Роль центрів інновацій знайшла своє втілення в Національному плані розвитку та в інших програмних документах щодо господарського розвитку країни.

Центри інновацій є пріоритетним інструментом реалізації Секторної операційної програми (СОП) - зростання конкурентоспроможності економіки.

Розвиток технологічних парків та інкубаторів безпосередньо записаний у пріоритеті 1, дії 3: «Створення сприятливих умов для розвитку підприємств». Як підтримку аналізованих ініціатив можемо розглядати інші діï. Наприклад, (1) «Зміцнення організацій, що підтримують діяльність підприємств» і (4) «Зміцнення співпраці між науково-дослідницькою сферою та економікою». Тут, передусім, ідеться про розвиток послуг підтримки бізнесу. Проекти можуть бути фінансованими 3 таких джерел: СОП «Розвиток людських ресурсів», пріоритет 2 - «Розвиток суспільства, що базується на знаннях», дія 3 -«Розвиток кадрів сучасної економіки та підприємництва»; 3 «Інтегрованої Операційної Програми Регіонального Розвитку» (IОПРР), наприклад, пріоритет 1 - «Розбудова та модернізація інфраструктури, що служить зміцненню конкурентоспроможності регіонів», дія 5 - «Інфраструктура інформаційного суспільства», пріоритет 2 «Зміцнення регіональної економічної бази та людських ресурсів», дія 3 «Розвиток кадрів регіональної економіки», дія 4 - «Регіональні інноваційні стратегії», пріоритет 3 - «Місцевий розвиток» [4].

У другій половині 2005 року кількість активних центрів інновацій становила 77, натомість кількість реалізованих ініціатив - 86. У порівнянні 3 2004 роком відбулося 60-відсоткове збільшення кількості суб'єктів цього типу. Так, висока динаміка має кілька джерел:

- $\quad$ розвиток нової категорії центрів - академічних інкубаторів підприємництва, більшість з яких почала свою діяльність наприкінці 2004 на початку 2005 років; 
- у сфері підтримки інноваційності почали діяти Наукові одиниці розвитку (HOP) та професійні об'єднання (Вища технічна організація та воєводські клуби техніки та раціоналізації);

- зростання активності недержавних ВН3;

- $\quad$ реалізація проектів пріоритету 1 , дії 3 - «Створення сприятливих умов для розвитку підприємств» у рамках Секторної операційної програми «Зростання конкурентоспроможності економіки».

Більшість нових центрів були створені в результаті реалізації нових завдань суб'єктами, ринкове становище яких стало стабільним. Нові інституції $є$ винятками. Ряд аналізованих центрів діють у формі проектів 3 обмеженою організаційною та технологічною самостійністю. У кількох випадках стикаємося зі специфічною ситуацією дублювання центрів, наприклад, у технологічному парку, що розвивається, діє технологічний інкубатор або ж академічний інкубатор підприємництва діє в центрі трансферу технологій.

Протягом останніх років важливим елементом підтримки розвитку інфраструктури трансферу технологій була діяльність Польського агентства розвитку підприємництва (ПАРП), а саме:

- опрацювання аналітичних звітів щодо можливості впровадження, звітів про вплив на середовище та бізнес-планів для 13-ти промислових і промислово-технологічних парків (завдання, реалізовані спільно 3 Агентством розвитку промисловості);

- допомога у створенні й керуванні 23-ма центрами трансферу технологій, технологічними парками та інкубаторами.

Табличя 2

\begin{tabular}{|c|l|c|c|}
\hline $\begin{array}{c}\text { № } \\
\text { п/п }\end{array}$ & \multicolumn{1}{|c|}{$\begin{array}{c}\text { Типи центрів } \\
\text { інновацій у Польщі }\end{array}$} & Діючі & $\begin{array}{c}\text { У процесі створення } \\
\text { (оціночні дані) }\end{array}$ \\
\hline $\mathbf{1}$ & \multicolumn{1}{|c|}{$\mathbf{2}$} & $\mathbf{3}$ & $\mathbf{4}$ \\
\hline 1. & $\begin{array}{l}\text { Центри трансферу } \\
\text { технології }\end{array}$ & 44 & 40 \\
\hline 2. & $\begin{array}{l}\text { Технологічні } \\
\text { інкубатори }\end{array}$ & 7 & 12 \\
\hline 3. & $\begin{array}{l}\text { Академічні інкубатори } \\
\text { підприємництва }\end{array}$ & 8 & 19 \\
\hline 4. & $\begin{array}{l}\text { Технологічні парки (в } \\
\text { тому числі науково- та } \\
\text { промислово- } \\
\text { технологічні парки) }\end{array}$ & $\mathbf{7 7}$ & $\mathbf{8 6}$ \\
\hline \multicolumn{2}{|}{ Загалом } & & \\
\hline
\end{tabular}

Джерело: [5] 
У результаті доопрацьовано ряд проектів: технологічних і промисловотехнологічних парків, технологічних та академічних інкубаторів. Важливою формою діяльності, що об'єднує середовища інституцій підтримки в окремих воєводствах, $\epsilon$ розроблення регіональних інноваційних стратегій. $\mathrm{У}$ майбутньому на регіональному рівні, який координується Маршалківськими управліннями, очікується зростання ролі механізмів підтримки та числа авторитетних осіб, котрі приймають рішення.

Польські центри інновацій функціонують у різних організаційноправових формах. Найчастіше стикаємося із суб'єктами сектора $R \& D$ $(43,2 \%)$, звідси $72 \%$ становлять академічні загальновузівські, міжфакультетні центри або центри факультетів.

Протягом найближчих років очікується збереження динаміки створення нових центрів у зв'язку з такими передумовами:

1) записані в Лісабонській стратегії пріоритети країн СС ведуть до того, що використання Структурних Фондів дедалі більше націлене на побудову економіки, базовану на знаннях, у тому числі на розвиток організацій та механізмів трансферу знань і технологій до малих і середніх підприємств;

2) розвиток нових форм активності ВН3; зростання конкуренції змушує їх до розширення сфери традиційних функцій ВНЗ (дослідницької дидактичної), включаючи до неї діяльність у сфері підприємництва й трансферу технологій;

3) реструктуризація Польської академії наук і одиниць розвитку та наукових;

4) пошук академічними установами додаткових джерел фінансування, розширення сфери завдань бюро патентів, мереж контактних пунктів i центрів кар'єри;

5) розширення сфери завдань і поступова модифікація частини діючих центрів підприємництва в технологічні центри, що реалізують програми підтримки інновацій та трансферу технологій до МСП.

Для зміцнення діючих і створення нових організацій підтримки та розвитку підприємництва ключове значення має діяльність у таких сферах:

1. Створення програм підтримки інноваційності, підприємництва та розвитку МСП на національному, регіональному й районному рівнях, усюди, де для найефективніших інституцій є кошти (що виділяються в рамках конкурсів).

2. Поліпшення управління та участі в діючих програмах підтримки.

3. Розвиток освіти для консультантів бізнесу й експертів трансферу технологій; навчання й удосконалення колективів у сфері організації трансферу технологій та охорони інтелектуальної власності: післядипломне навчання, аспірантура, навчальні поїздки та стажування за кордоном у відомих ВНЗ США та Свропи (а також китайських, тайванських та ізраїльських). 
4. Підвищення рівня вмінь опрацювання й управління програмами трансферу та комерціалізації технологій.

5. Розвиток інфраструктури лобіювання в регіонах, на національному рівні, а також при європейських комісіях; опрацювання та інформування про «історії успіху».

6. Розвиток таких регіональних систем інновацій, як мережі співпраці адміністрацій, науково-дослідних інституцій, центрів інновацій та підприємництва.

7. Допомога в підготовці аналітичних звітів про можливості виконання і складання бізнес-планів для нових центрів та забезпечення їх рівномірного розвитку по всій країні.

8. Розвиток міжнародних контактів і співпраці.

9. Розробка системи моніторингу діяльності організацій та програм підтримки.

Наприклад, індустріальний науково-технологічний парк у Сувалках, енергетичний та авіаційний кластери у Жешуві було започатковано в індустріально відсталих у недалекому минулому регіонах, проте нині, незважаючи на критичне ставлення до них деяких наукових колективів у столиці країни, вони активно діють, створюючи нові робочі місця та сприятливий інноваційний клімат.

Успішна діяльність гравців інноваційного поля на регіональному рівні передбачає: політики;

- активну участь у розвитку регіону;

- важливу роль у реалізації регіональної інноваційної стратегії;

- співробітництво та кооперацію регіональних технологічних та індустріальних кластерів;

- участь у спільних технологічних і наукових проектах;

- оптимальне використання центрального й місцевого бюджету для економічного розвитку;

- узгоджену роботу державних органів влади, відповідальних за розвиток i реалізацію національної наукової та інноваційної політики (міністерств, національних агентств, місцевих адміністрацій тощо);

- участь у виконанні національних програм розвитку;

- участь у пошукових наукових дослідженнях.

В Польщі, у Гданьскому інституті ринкової економіки було проведено дослідження регіональних інноваційних систем (РIC). Згідно 3 ним, можна виділити такі їх сильні сторони:

- діяльність, спрямована на фінансову (в основному зі структурних фондів) підтримку інноваційної діяльності;

- наявність фінансових інструментів для підтримки НДДКР; 
- зростаюча обізнаність та інноваційна культура підприємств, установ та місцевих органів влади;

- зростання кількості інноваційно-активних підприємств (збільшується рівень витрат на НДДКР та рівень зайнятості в цій сфері);

- зростання кількості установ 3 підтримки інновацій та установ 3 підтримки бізнесу;

- високий конкурентний потенціал фірм в деяких (традиційних для Польщі) галузей: харчовій промисловості, галузі машинобудування та деревообробної промисловості;

- збільшення кількості товарів і послуг інноваційного характеру;

- високий рівень активності бізнес-середовища;

- поліпшення доступу фірм до трансферу технологій на регіональному, національному та міжнародному рівнях;

- зростання частки експорту з високим ступенем переробки товарів;

- реалізація європейських проектів, пов'язаних 3 інноваційним розвитком;

- динамічний розвиток сектора малого і середнього бізнесу.

Між тим необхідно також окреслити деякі слабкі сторони РІС Польщі:

- кваліфікація деяких співробітників установ НДДКР $є$ занадто низькою з точки зору їх здатності брати участь у підвищенні ефективності інноваційної діяльності;

- обмежені можливості співпраці з науково-дослідними установами та іншими підприємствами; застарілі технології та технічне обладнання багатьох підприємств;

- обмежена кількість стимулів для інноваційної діяльності (без значних податкових пільг або інвестиційної підтримки);

- обмеженість власних коштів підприємств для інвестування в інноваційну діяльність.

\section{Чехія}

Наприкінці XX - на початку XXI ст. наукова система Чехії намагалась адаптуватись до політичних та економічних змін у країні. На сьогодні високого рівня розвитку сучасна чеська наука досягла завдяки активній підтримці з боку держави та реформуванню наукової системи.

На сьогодні уряд Чехії створює умови для надання ефективної державної підтримки системі НДДКР, що задовольняє потреби економіки країни на сучасному етапі адаптації до стандартів Свропейського Союзу. Це зводить до мінімуму втручання держави в наукову роботу, спрощує механізми фінансування 3 державного бюджету, стимулює конкуренцію в галузі науки i техніки, підтримує інтеграцію наукових досліджень у діяльність університетів, зміцнює зв'язки між університетами й Академією наук, а також надає підтримку міжнародній науково-інноваційній співпраці [6]. 
За останні роки державні асигнування на науково-дослідну діяльність у Чехії виділяються в основному для неуніверситетських наукових центрів. Основні фінансові надходження, що направлені на розвиток чеської науки, розподіляються між Академією наук ЧР і Міністерством освіти, молоді та спорту. Невелика частина коштів 3 державного бюджету надходить до Міністерства промисловості і торгівлі, Міністерства охорони здоров'я, Міністерства сільського господарства, Міністерства охорони навколишнього середовища, Міністерства транспорту для фінансування цільових індустріальних програм i наукових проектів, що підвищують конкурентоспроможність чеської економіки. У цілому у 2010 р. фінансові надходження на розвиток науково-дослідної діяльності в Чехії становили близько 1,56 \% ВВП (з цих коштів 49 \% асигновано приватним сектором, $41 \%$ - державою, $10 \%$ - закордонними інвесторами).

Протягом останніх років Чехія дедалі більше приділяє уваги розвитку науки, однак тільки за рахунок державного бюджету наука не може повноцінно розвиватись, тому фінансування наукових досліджень здійснюється через впровадження системи грантів. Урядом Чехії, університетами та Академією наук ЧР створено фонди, що фінансують фундаментальні дослідження. Окремі наукові дослідження фінансуються агентствами, які створені міністерствами і відомствами, великими промисловими підприємствами, що зацікавлені в наукових розробках. Важливу роль у розподілі коштів відіграє Агентство з технологій (засноване у 2009 р.), що підтримує програми, прикладні соціальні наукові проекти, дослідно-конструкторські розробки, інноваційні дослідження тощо.

У Чехії великого значення набули зв'язки науки 3 промисловістю, впровадження наукових розробок у виробництво. У початковий період реформ передбачалось, що промислові науково-дослідні установи трансформуються в регіональні технологічні парки. Дослідницькі організації заснували Асоціацію наукових парків, яка мала створити базу для реорганізації науково-дослідних інститутів. Для впровадження технологій у виробництво було створено Асоціацію трансферу технологій й обміну. У політичних колах ця позиція не знайшла підтримки, у результаті чого 105 наукових установ були приватизовані і у своїй діяльності стали менше займатися науковими дослідженнями [7]. Були запроваджені державні програми «Парк» i «Трансферт», які надавали реальну підтримку малим $\mathrm{i}$ середнім підприємствам. Також відіграють важливу роль у фінансуванні наукових проектів місцеві бюджети.

Академічний сектор переорієнтувався на технічні науки і прикладні дослідження. Це створило можливість налагодити більш тісні контакти 3 керівництвом наукових і технологічних парків. Науково-технологічні парки виникли і в самій Академії наук, хоча вони виявилися менш продуктивними, ніж створені на базі промислових підприємств. 
Поступово сформувалися зв'язки між університетами й промисловими фірмами. Вони набули характеру дослідницьких експертиз нових технологій i наукових розробок, що застосовувались у виробництві. Однак в університетах Чехії така практика займає невеликий відсоток і у фінансовому відношенні пріоритет надається саме освіті, а не науковим дослідженням.

Серед найвідоміших університетів Чехії слід відзначити:

- Карлів університет;

- $\quad$ Університет ім. Т. Г. Масарика (м. Брно);

- Університет Західної Богемії (м. Пльзень);

- Вищу технічну школу (м. Брно);

- $\quad$ Вищу гірничу школу - технічний університет (м. Острава);

- Університет ім. Ф. Палацького (м. Оломоуц);

- Чеський політехнічний університет (м. Прага); (м. Брно);

- Менделівський сільськогосподарський та лісотехнічний університет

- Чеський сільськогосподарський університет (м. Прага).

Усього в Чехії понад 35 вищих навчальних закладів. При університетах діють установи, які ведуть науково-дослідну діяльність. Зокрема, в університеті ім. Т. Г. Масарика функціонують: Міжнародний інститут політології, Інститут обчислювальної техніки, у Карловому університеті діють Інститут політології і міжнародних відносин, Інститут економіки, Інститут соціології, Інститут журналістики тощо.

За результатами дослідження, проведеного у 2010 р. іспанською науководослідною групою Scimago, було визначено рейтинг Академії наук ЧР i Карлового університету, згідно з яким ці установи займають почесне п’яте i шосте місця серед науково-дослідних інститутів та університетів Центральної і Східної Європи. У цілому рейтинг охоплює 172 науково-дослідних інститути і університети зі Східної Європи та 2833 установи у всьому світі. У світовому рейтингу АН ЧР і Карловий університет зайняли 97 та 231 місце відповідно [8].

Основу для розвитку сучасної науково-технічної співпраці між Чеською Республікою та Україною було закладено підписанням угоди між урядом ЧР та Кабінетом Міністрів України про економічне, промислове та науковотехнічне співробітництво, угоди про співробітництво в галузі культури між Міністерством культури України та Міністерством культури ЧР на 20122014 рр., угоди про співробітництво в галузі освіти та науки на 2012-2015 рр. між Міністерством освіти і науки, молоді та спорту України і Міністерством освіти, молоді та спорту ЧР. Договірно-правова база 3 питань науковотехнічного співробітництва між Чехією й Україною достатньо широка та охоплює різноманітний спектр взаємодії сторін у зазначеній галузі. Науковотехнічне співробітництво між Україною та ЧР передбачає спільні науковотехнологічні та науково-дослідні проекти; обмін науковцями, фахівцями, дослідниками та експертами з метою виконання наукових програм і проектів; обмін науковою $\mathrm{i}$ технічною інформацією, документацією, а також 
лабораторними зразками та обладнанням; організацію та проведення спільних наукових конференцій, симпозіумів, семінарів, виставок. Крім того, діє ряд прямих угод про співробітництво між вищими навчальними закладами України та Чехії.

Співробітництво в галузі освіти відбувається також по лінії обміну студентами, аспірантами та викладачами вищих навчальних закладів обох країн.

Характерною рисою міжнародної співпраці наукових організацій Чехії став перехід на багатосторонню форму співробітництва 3 іноземними науковими установами. Особливо інтенсивно почала розвиватись міжнародна наукова співпраця 3 європейськими країнами. Завдяки підписаній угоді про асоційоване членство, країна отримала повний доступ до всіх програм і заходів Європейського Союзу в галузі науки і техніки.

Слід наголосити, що головним чинником інноваційного процесу в країні $є$ промислові розробки. При цьому пріоритетними вважаються такі високотехнологічні галузі, як автомобілебудування та авіабудування, інформаційні, телекомунікаційні, нано- і біотехнології. Цільові дослідницькі програми здійснюють 22 державні організації та відомства. Діє Центр авіаційних і космічних досліджень.

Значну роль у забезпеченні інноваційного розвитку країни відведено установам Чеської академіі наук та вищим навчальним закладам. В інститутах і університетах створено спеціалізовані технологічні центри, які надають послуги підприємцям в області трансферу технологій. Ці центри та інші спеціалізовані дослідницькі організації взаємодіють 3 промисловими підприємствами, створюючи консорціуми для роботи над конкретними проектами.

На особливу увагу заслуговує практика створення так званих інноваційних підприємницьких інкубаторів та науково-технологічних парків, яка набула широкого застосування в країні. Програми інноваційних інкубаторів надають підприємницьким суб'єктам низку фінансових та інших інструментів та послуг підтримки. Управління програмами здійснюється менеджментом інноваційних інкубаторів. У випадку науково-технологічних парків йдеться про великі проекти, які надають адміністративні та лабораторні приміщення в оренду підприємницьким та державним структурам, вищим навчальним закладам, а також малим інноваційним фірмам. Обсяг послуг тут менший, ніж в інкубаторах, але орендатори можуть використовувати вигоди високого рівня концентрації інноваційних суб'єктів в одному місці. За результатами міжнародного дослідження консалтингової компанії «Ernst\&Young», нині Чехія входить в десятку країн, найбільш привабливих для вкладення інвестицій у розвиток науково-технологічних парків.

Особливості діяльності інноваційних структур країн В-4 наведено в таблиці 3. 
Таблиия 3

\section{Особливості діяльності інноваційних структур країн \\ Вишеградської групи}

\begin{tabular}{|c|c|c|c|c|c|}
\hline \multirow{2}{*}{$\begin{array}{l}\text { № } \\
\text { п/II }\end{array}$} & \multirow{2}{*}{ Ознаки } & \multicolumn{4}{|c|}{ Країни Вишеградської групи } \\
\hline & & Словаччина & Угорщина & Польща & Чехія \\
\hline 1 & 2 & 3 & 4 & 5 & 6 \\
\hline 1. & $\begin{array}{l}\text { Види } \\
\text { інноваційни } \\
\text { х структур }\end{array}$ & $\begin{array}{l}\text { - Науково- } \\
\text { дослідницьки } \\
\text { й інститут; } \\
\text { - Дослідниць } \\
\text { кий центр; } \\
\text { - Технологіч } \\
\text { ний } \\
\text { (науковий) } \\
\text { парк; } \\
\text { - Промислов } \\
\text { ий } \\
\text { (індустріальн } \\
\text { ий) парк; } \\
- \text { Кластери } \\
\text { (Університет } \\
\text { Коменського } \\
\text { в Братиславі } \\
\text { [9], Технічний } \\
\text { університет } \\
\text { м. Кошиче, } \\
\text { Науково- } \\
\text { дослідний } \\
\text { центр } \\
\text { університету } \\
\text { Жиліна [10]) }\end{array}$ & $\begin{array}{l}\text { - Науково- } \\
\text { дослідницьк } \\
\text { ий інститут; } \\
\text { - Науковий } \\
\text { парк; } \\
\text { - Індустріа } \\
\text { льний парк; } \\
\text { - Бізнес - } \\
\text { інкубатор; } \\
\text { - Стартап } \\
\text { компанії; } \\
\text { - Технологі } \\
\text { чні } \\
\text { платформи; } \\
- \text { Кластери } \\
\end{array}$ & 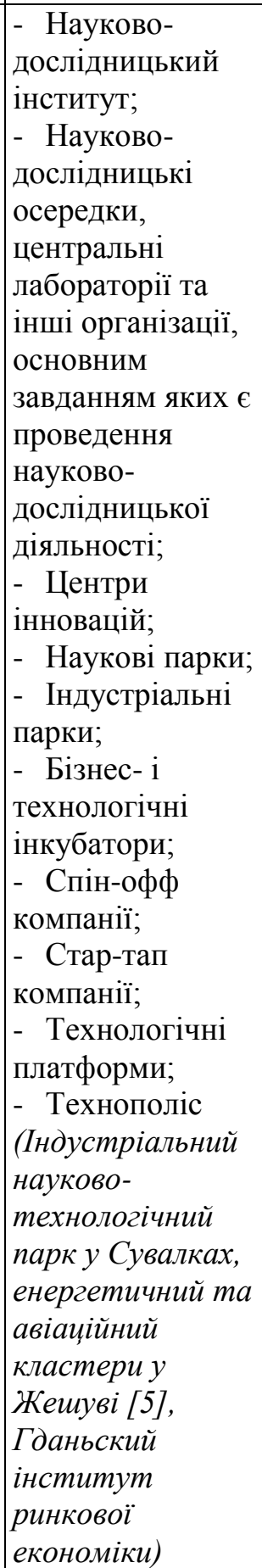 & 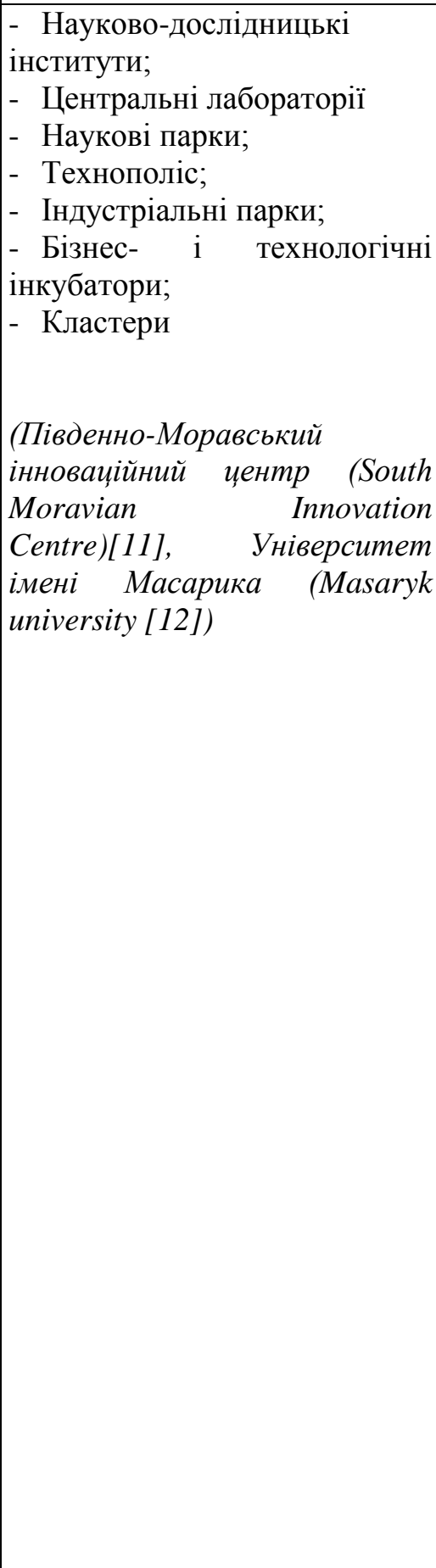 \\
\hline 2. & \begin{tabular}{|l|} 
Мета \\
створення
\end{tabular} & \multicolumn{4}{|c|}{$\begin{array}{l}\text { 1. Розвиток фундаментальних досліджень } 3 \text { подальшою комерціалізацією } \\
\text { результатів. } \\
\text { 2. Посилення конкурентних переваг певної території. } \\
\text { 3. Децентралізація і демократизація управління освітою. } \\
\text { 4. Підвищення автономії ВН3. }\end{array}$} \\
\hline
\end{tabular}




\begin{tabular}{|c|c|c|}
\hline & & $\begin{array}{l}\text { 5. Громадський контроль за рішеннями міністерств, розподілом коштів } \\
\text { бюджету, діяльністю ВНЗ. } \\
\text { 6. Повна ліквідація монополії держави на створення навчальних програм і } \\
\text { підручників. } \\
\text { 7. Вільна навчальна і економічна діяльність вищих навчальних закладів. } \\
\text { 8. Комерціалізація результатів дослідницької діяльності. } \\
\text { 9. Посилення конкурентних переваг продукції підприємств-резидентів, } \\
\text { зниження витрат, матеріало-, енерго-, трудомісткості. }\end{array}$ \\
\hline 3. & $\begin{array}{l}\text { Зміст } \\
\text { діяльності }\end{array}$ & 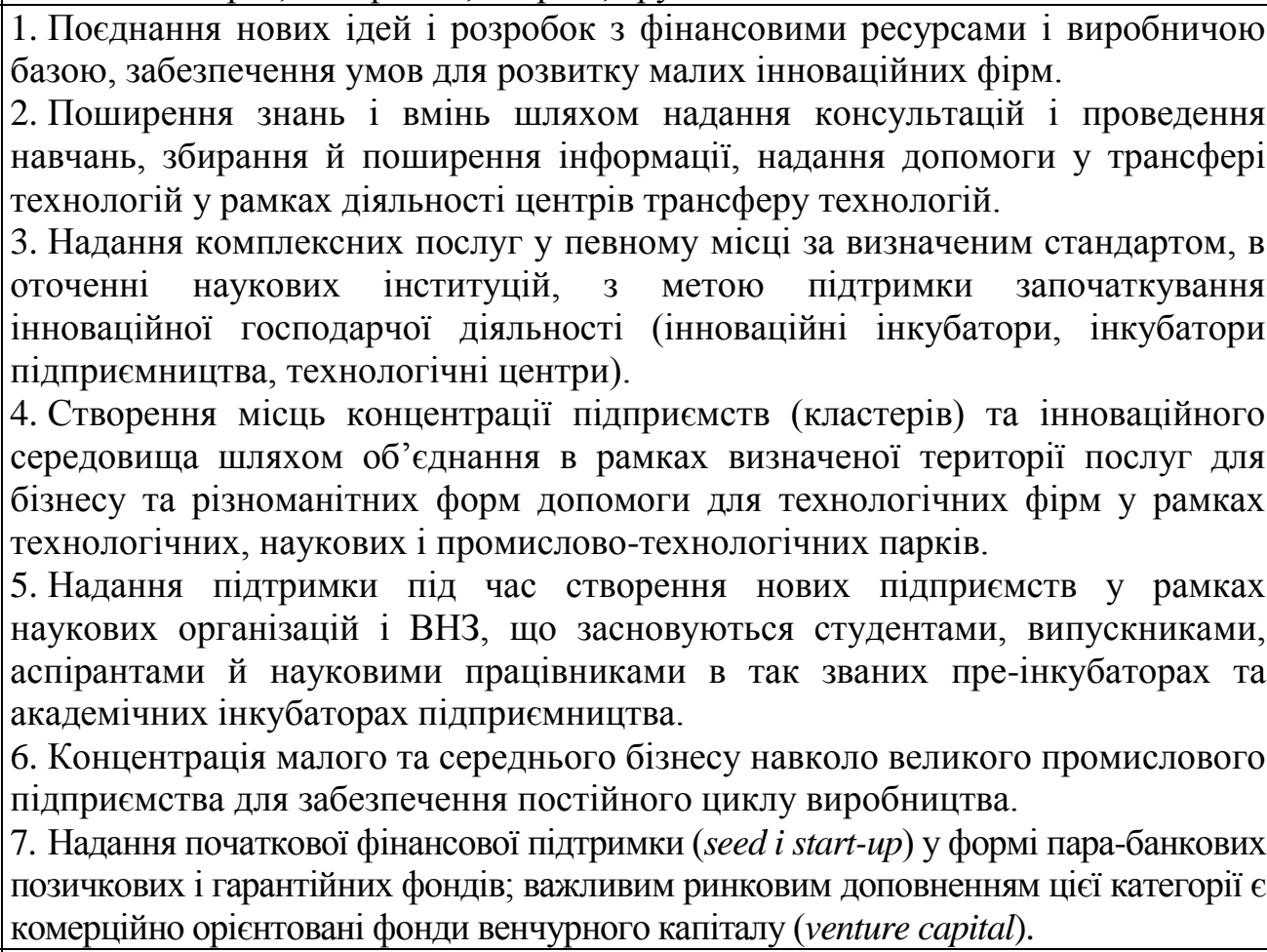 \\
\hline 4. & Функції & $\begin{array}{l}\text { - Поєднання наукових досліджень у передових і нових галузях } \\
\text { наукомістким промисловим виробництвом; } \\
\text { - вдосконалення системи освіти, націленої на відкритість, інноваційність та } \\
\text { підприємництво; } \\
\text { - розвиток дослідницької діяльності } 3 \text { метою вивільнення внутрішніх } \\
\text { факторів розвитку регіону; } \\
\text { - побудова інфраструктури інформативного суспільства; } \\
\text { - оптимальне використання фондів ЄС для реалізації РІС; } \\
\text { - розбудова інституційних форм співпраці академічного середовища, } \\
\text { регіональної влади та представників бізнесу; } \\
\text { - стимулювання переходу від експериментального виробництва до масового } \\
\text { комерційного освоєння нової інноваційної продукції; } \\
\text { - зростання кількості установ з підтримки інновацій та установ з підтримки } \\
\text { бізнесу; } \\
\text { - розвиток малого та середнього бізнесу, збільшення кількості робочих місць, } \\
\text { впровадження наукових досягнень у високотехнологічні підприємства; } \\
\text { - збільшення кількості товарів і послуг інноваційного характеру. }\end{array}$ \\
\hline 5. & $\begin{array}{l}\text { Результати } \\
\text { діяльності }\end{array}$ & $\begin{array}{l}\text { 1. Створення регіональних інноваційних систем (РІС). } \\
\text { Центри інновації є суттєвим елементом кожної сучасної інноваційної системи } \\
\text { країни, яка розбудовує основи економіки, базовані на знаннях. Вони } \\
\text { відповідають за побудову платформи діалогу та співпраці світу науки й } \\
\text { бізнесу, створюючи умови для ефективного трансферу інформації, знань і } \\
\text { технологій. Їх активність включає: } \\
\text { - ініціювання та організацію співпраці всіх партнерів, необхідних для }\end{array}$ \\
\hline
\end{tabular}




\begin{tabular}{|c|c|c|}
\hline & & $\begin{array}{l}\text { ефективної реалізації інноваційного процесу; } \\
\text { - визначення інноваційних потреб фірм і комерційних можливостей у рамках } \\
\text { наукових організацій; } \\
\text { - удосконалення механізмів трансферу технологій; } \\
\text { - створення необхідних для економічного розвитку партнерства різних } \\
\text { приватних і публічних суб'єктів. } \\
\text { 2. Створення регіональної системи інновацій - тривалого партнерства між } \\
\text { промисловістю, інституціями оточення бізнесу, науково-дослідними } \\
\text { одиницями, урядовою адміністрацією та самоврядуванням } 3 \text { метою } \\
\text { прискорення інноваційної діяльності в регіоні. } \\
\text { 3. Виробництво та комерціалізація інноваційної продукції. } \\
\text { 4. Створення та підтримка малих наукомістких фірм. } \\
\text { 5. Поширення інноваційної продукції. }\end{array}$ \\
\hline 6. & $\begin{array}{l}\text { Учасники та } \\
\text { розміщення }\end{array}$ & $\begin{array}{l}\text { 1. ВНЗ, навчальна організація, лабораторії, виробничі підприємства, } \\
\text { транспортна інфраструктура тощо; агломерація, місто або наукове містечко. } \\
\text { 2. Промислові підприємства, фінансові установи, органи місцевої влади. } \\
\text { Територія поблизу ВНЗ, НДІ, промислового підприємства. Компактне } \\
\text { розташування. } \\
\text { 3. Організації сфери технічної та соціальної інфраструктури. Відокремлена } \\
\text { територія з площами великих підприємств. }\end{array}$ \\
\hline 7. & $\begin{array}{l}\text { Роль } \\
\text { держави }\end{array}$ & $\begin{array}{l}\text { Обов'язкова підтримка з боку держави: здійснення інвестицій у розвиток } \\
\text { інфраструктури, капіталовкладення у прикладні дослідження, державні } \\
\text { замовлення, податкові пільги. }\end{array}$ \\
\hline
\end{tabular}

\section{СПИСОК ВИКОРИСТАНИХ ДЖЕРЕЛ}

1. Innovation Policies in the Visegrad Countries (Інноваційна політика країн Вишеградської групи) [Електронний ресурс]. - Режим доступу: http://ibs.org.pl/projekty/files/Visegrad/Publication.pdf

2. The Technical University of Košice [Електронний ресурс]. -Режим доступу: https://www.tuke.sk/tuke/university

3. Інструменти підтримки інноваційності малих i середніх підприємств: досвід Польщі та Європейського Союзу [Електронний ресурс]. - Режим доступу: http://www.agroin.org/statti/polsha.pdf

4. Національний план розвитку 2004-2006 pp., ухвалений Радою Міністрів Польщі 14 січня 2003 року, скоригований відповідно до рішення Ради Міністрів 311 лютого 2003 року, Варшава, лютий 2003, С. 91-125.

5. Бонковскі А. Інструменти підтримки інноваційності малих i середніх підприємств: досвід Польщі та Європейського Союзу/ Александр Бонковскі, Міхал Клепка, Кшиштоф Матусяк, Сжи Стшелєц, Кшиштоф Засядли. - Познань-Київ. - 2005. - 186 с.

6. Filacek A. Social Sciences and Humanities in Czech Republic // Theory of Science. - 2004. - Vol. 24, N 1. - P. 5-34.

7. Водопьянова Е. Страны Центральной и Восточной Европы: наука в пути / Е. Водопьянова // Мировая экономика и международные отношения. 2000. - № 10. - С. 71-77.

8. Академия наук Чехии и Карлов университет признаны лучшими в Восточной Европе - Scimago [Электронный ресурс]. -Режим доступа: http://www.novoya.com/info/1500.html 
9. Comenius University in Bratislava [Електронний ресурс]. - Режим доступу: https://uniba.sk/

10. Technical University of Kosice and University of Zilina [Електронний pecypc]. - Режим доступу: http://www.tuke.sk/tuke?set_language=en\&cl=en

11. South Moravian Innovation Centre [Електронний ресурс]. - Режим доступу: https://www.jic.cz/en/

12. Masaryk university [Електронний ресурс]. - Режим доступу: https://www.muni.cz/

\section{REFERENCES}

1. Innovation Policies in the Visegrad Countries. Retrieved from: http://ibs.org.pl/projekty/files/Visegrad/Publication.pdf

2. The Technical University of Košice. Retrieved from: https://www.tuke.sk/tuke/university

3. Instrumenty pidtrymky innovatsiynosti malykh i serednikh pidpryyemstv: dosvid Pol'shchi ta Yevropeys'koho Soyuzu [Tools for innovation support for small and medium enterprises: the experience of Poland and the European Union]. agroin.org. Retrieved from: http://www.agroin.org/statti/polsha.pdf

4. Natsional'nyy plan rozvytku 2004-2006 rr., ukhvalenyy Radoyu Ministriv Pol'shchi 14 sichnya 2003 roku, skoryhovanyy vidpovidno do rishennya Rady Ministriv z 11 lyutoho 2003 roku, [National Development Plan 2004-2006, adopted by the Council of Ministers of Poland on January 14, 2003, adjusted according to the decision of the Council of Ministers from February 11, 2003]. 91125.

5. Bonkovski, A. (2005). Instrumenty pidtrymky innovatsiynosti malykh i serednikh pidpryyemstv: dosvid Pol'shchi ta Yevropeys'koho Soyuzu [Tools for innovation support for small and medium enterprises: the experience of Poland and the European Union]. 186.

6. Filacek, A. (2004). Social Sciences and Humanities in Czech Republic. Theory of Science. Vol. 24, 1, 5-34.

7. Vodop'yanova, Ye. (2000). Strany Tsentral'noy i Vostochnoy Yevropy: nauka v puti [Countries of Central and Eastern Europe: Science in transit]. 10, 71-77.

8. Akademiya nauk Chekhii i Karlov universitet priznany luchshimi v Vostochnoy Yevrope [The Czech Academy of Sciences and the Charles University are recognized as the best in Eastern Europe]. Retrieved from: http://www.novoya.com/info/1500.html

9. Comenius University in Bratislava. Retrieved from: https://uniba.sk/

10. Technical University of Kosice and University of Zilina. Retrieved from: http://www.tuke.sk/tuke?set_language=en\&cl=en

11. South Moravian Innovation Centre. Retrieved from: https://www.jic.cz/en/

12. Masaryk university. Retrieved from: https://www.muni.cz/ 